\title{
On the Symbolic Significance of To Kill a Mockingbird*
}

\author{
Liu Xi, Zhang Li-li \\ Changchun University, Changchun, China
}

\begin{abstract}
To Kill a Mockingbird is one of the favorite novels among the British teenagers. It tells the physical and the mental growth of a little girl, in which she learns a lot of lessons from what she has experienced. The major event involving the trial of the black young man who is actually innocent displays the main social problem-racial prejudice in that age. The paper aims at analyzing the symbolic significance of the book. From the perspectives of the characters, Gothic motifs and the mockingbird, the paper tries to reveal the evil side of the society and that of the human nature.
\end{abstract}

Keywords: character, Gothic motifs, mockingbird, symbolic significance

\section{Introduction}

Harper Lee is an American writer, who earns her fame worldwide by the novel To Kill a Mockingbird, which is widely prized by the critics and other novelists by its liveliest sense of life and the warmest humor.

To Kill a Mockingbird focuses on the story which occurs in the small town Maycomb that suffers the severe Great Depression. Scout and Jem were brought up by their father Atticus, a middle-aged lawyer, for their mother died in their childhood. During a summer vacation, they ventured to a mysterious house, where there lived an eccentric person-Boo Radley, who was actually a victim of his father's indifference. However, they were scared of death by the large shadow of Boo's brother and rushed home. Late at night, Atticus was informed of the case in which the black young man Tom was accused of raping Mayella Ewell. Atticus promised to defend for Tom. Tom was sentenced to death although Atticus showed Tom's innocence by the self-evident testimony. After the trial ended, life returned to quietness, but Bob Ewell, Mayella Ewell's father, vowed to retaliate for he felt that he was fooled by Atticus and Judge. Scout and Jem were attacked by Bob Ewell on the late night of Halloween. At the dangerous moment, they were saved by Boo Radley, who became a real human being rather than a freak in their mind. The major event involving the trial of the black young man who was actually innocent displayed the main social problem - racial prejudice in that era.

To analyze the symbolic significance comprehensively, this paper aims to analyze the symbolic significance of the book. From the perspectives of the characters, Gothic motifs, and the mockingbird, the paper tries to reveal the evil side of the society and that of the human nature.

\section{The Symbolic Significance Reflected by Characters}

"Symbolism was a late 19th art movement of French, Russian, and Belgian origin in poetry and other arts.

\footnotetext{
* This paper is a part of the results of the research program "The Study of Counter-Elite Essentiality in American Post-modernism Novels" (2013, No.265) the authors have participated in.

Liu Xi, M.A., lecturer, School of Foreign Languages, Changchun University.

Zhang Li-li, M.A., lecturer, School of Foreign Languages, Changchun University.
} 
In literature, the style had its beginnings with the publication Les Fleurs du mal by Charles Baudelaire" (Conway, 2007, p. 16). It involves the nature of the things and expresses their own views or inner hidden emotions through the specific images.

In To Kill a Mockingbird, the author Harper Lee uses memorable characters to explore civil rights and racism in the segregated southern United States of the 1930s.

In the novel, Atticus represented morality and reason. As a character, Atticus was even-handed throughout the story. He was one of the very few characters who never had to rethink his position on an issue.

His parenting style was quite unique in that he treated his children as adults, honestly answering any question they had posed. He used all these instances as an opportunity to pass his values on to Scout and Jem. For all of his mature treatment to Jem and Scout, he patiently recognized that they were children and that "They would make childish mistakes and assumptions" (Harper, 1988, p. 125). Ironically, Atticus's insecurity seemed to be in the child-rearing department, and he often defended his ideas about raising children to those more experienced and more traditional.

His stern but fair attitude towards Jem and Scout reached into the courtroom as well. "He politely proves that Bob Ewell is a liar; he respectfully questions Mayella about her role in Tom's crisis" (Harper, 1988, p. 29). One of the things that his longtime friend Miss Maudie admired about him was that Atticus Finch was the same in his house as he was on the public streets. The only time he seriously lectured his children was on the evils of taking advantage of those less fortunate or less educated, a philosophy he carried into the animal world by his refusal to hunt. And although most of the town readily pins the label "trash" on other people, Atticus reserved the distinction for those people who unfairly exploited others.

Atticus believed in justice and the justice system. He did not like criminal law, yet he accepted the appointment to Tom Robinson's case. He knew before he began that he would lose this case, but that did not stop him from giving Tom the strongest defense he possibly could. And, importantly, Atticus did not put so much effort into Tom's case, not because he was an African American, but because he was innocent. Atticus felt that the justice system should be color blind, and he defended Tom as an innocent man, not a man of color.

Atticus was the adult character least infected by prejudice in the novel. He had no problem with his children attending Calpurnia's church, or with a black woman essentially raising his children. He admonished Scout not to use racial slurs, and was careful to use the terms acceptable for his time and culture. He went to Helen's home to tell her of Tom's death, which meant a white man spending time in the black community. Other men in town would have sent a messenger and left it at that. His lack of prejudice did not apply only to other races, however. He was unaffected by Mrs. Dubose's caustic tongue, Miss Stephanie Crawford's catty gossip, and even Walter Cunningham's thinly veiled threat on his life. He did not retaliate when Bob Ewell spat in his face because he understood that he had hurt Ewell's pride - the only real possession this man had. Atticus accepted these people because he was an expert at climbing into other people's skin and walking around in it.

From what discussed above, we know that Atticus was responsible and he believed in justice. He tried his best to fight against racial prejudice. Therefore, the symbolic significance of Atticus was morality and reason.

\section{The Symbolic Significance Reflected by Gothic Motifs}

A Gothic novel is characterized by its story which happens in the past, in which the background is mostly ruined, wild, and deserted. "The Gothic story often takes place in a certain gloomy castle furnished with dungeons, subterranean passages, and sliding panels, in which the atmosphere is dark, mysterious, horrible and 
full of suspense" (Claudia, 1994, p. 106). It puts more emphasis on the motifs, such as terrible violence, incest, haunted ghost, and supernatural events. Gothic novels produce incisive and wide-ranging influence on American literature, which is adopted by many American writers. "The principal aim of the Gothic novels is to evoke chilling terror by exploring horrible violence" (Ellis, 2000, p. 68). "Horrible violence can stimulate the psychological organs, resulting in a strong shock effect" (Marie, 1998, p. 55). Therefore, it becomes the important motif of the Gothic novel. Early Southern Gothic novels center on primarily performance-based violence. In addition to the pursuit of excitement stimulated by horrible violence, the Southern Gothic novels also express the dark side of the life and society.

In To Kill a Mockingbird, Harper Lee successfully infiltrates the Gothic feature in the novel to highlight the unique art charm of the work, which displays the author's superb writing skills including the horrible violence, the disfigured love, and the imprisonment.

In a broader sense, horrible violence invaded the town. Violence formed a feeling of thrilling violence lying beneath the tranquil, peaceful, and stable surface of the small town, Maycomb. The lynching by the mob can serve as a good example. Tom Robinson was threatened to be lynched by a mob composed of the poor from the Old Sarum. In the Deep South, lynching has been prevailing for many years, even in the 1930s, it still existed. In To Kill a Mockingbird, after Tom was put into prison and transferred into the Maycomb jail, he was faced with the danger of lynching. Atticus ventured to protect Tom by guarding at the gate of the jail, different from those who broke into Atticus's house the previous night, the mob members were strangers, from the Old Sarum to abduct and lynch Tom. Most of the people in the Old Sarum mod were poor white farmers. It was the racism of the mob members that shrouded the humanity, worthiness, and essential goodness of them. "It was a summer's night, but the men were dressed, most of them in overalls and denim shirts buttoned up to the collars" (Harper, 1988, p. 43). The violence by the mob showed that the racial discrimination was on a rampage in the remote town, which influences the townsmen profoundly.

In To Kill a Mockingbird, the violence among the school kids gives the hint that one would never be tamed or civilized without proper training, which highlighted the author's perceptive about the moral and intellectual education in one's childhood. Because exploration of the novel's larger moral questions takes place within the perspective of children, the education of children is necessarily involved in the development of all of the novel's themes.

School violence used by the children could be seen from the cases of Scout and her classmates. Being a young lady, Scout was often in overalls and exhibited violence by fighting with the other children with her fists. Walter Cunningham was the first one that was bitten by Scout. Violence was also exhibited by the 1st grade children. When the woman teacher was bullied by the boy from the Ewells, the student, Little Chuck warned him when Burris Ewell turned back.

The domestic violence happened in all ranks of families. In the decent and poverty Ewells, violence was reflected by Bob Ewell who was good for nothing but a drunken bully. In the eccentric Radley's family, violence occured in domestic circumstances. After confining to the house as a prisoner for many years, Boo stabbed his dad in the leg with scissors for no direct reason. Even in the civilized and blessed family, Finch family, there was a history connected with violence and madness. Cousin Joshua, who wrote a book with the unlikely religious title "Meditations of Joshua St. Clair", was locked up in the state mental institution, because he attempted to shoot the president of the university, but finally the gun was blown up in his hand. 
In the Gothic tradition, violence constantly threatens to break out beneath the superficial tranquility. Counterbalancing the horrible violence is the moral grandeur in the small town values, which are manifested in the whole book.

"In the 19th century of American Gothic novels, disfigured love is the chief Gothic motif, which embodies incest, intermarriage and deformed love" (Meyer, 2004, p. 79). In the Gothic novels, the personalities of the characters are mainly eccentric and grotesque whose root is lack of love. They are distorted by the disfigured love and become the sacrificial lambs. The author expresses her perspective of love by disposing the tragedies made by disfigured love.

Disfigured love firstly contained incest which occurs between brother and sister, or father and daughter. Actually, Mayella was raped by her father who committed incest. The distortion of Mayella by the disfigured love forced her to dare break the societal code to make sexual attempting to the robotic black young man. The Gothic subjects of sexual violence presented in Mayella Ewell's actual rape by her father, her sexual attraction to Tom, and her false accusation of rape by Tom.

The distortion of Mayella is a mirror to reflect the social and family circumstances. Mayella was at the bottom of the white society, but it was superior to the black. At the same time, she suffered from her father's sexual violence now and then. "The affection by the distorted social ranks and family background is the cause of the aberrant psychological states of Mayella" (Frank, 2004, p. 90). In a sense, the lack of a real father image forced Mayella to move from incest to miscegenation. Tired of sexual violence from her father, Mayella protected him by making attraction to Tom. To some degree, Mayella's attraction to Tom was a more healthy impulse to join with the outside world. Mayella's false accusation of raping by the black young man was the product of that society at that time.

The common Gothic motifs include violence, revenge, disfigured love, and insanity in general, horrible violence, disfigured love, and imprisonment in To Kill a Mockingbird in particular. The major themes are expressed clearly by using the Gothic motifs at all levels, which expresses themselves into the readers' mind.

\section{The Symbolic Significance Reflected by the Mockingbird}

The title "To Kill a Mockingbird" has very little literal connection to the plot, but it carries a great deal of symbolic weight in the book. In this story, because innocents are destroyed by evil, the "mockingbird" comes to represent the idea of innocence. Thus, to kill a mockingbird is to destroy innocence.

As for the symbolic significance of the mockingbird, it represents the existence of social inequality. Clearly, in Tom Robinson's case, Lee's characters to deal with racial prejudice are showed. Black people occupied the lowest class level of Maycomb society as Maycomb's white population of every class wasted no time reinforcing their rigid class rules. The fact that Atticus realized that he had no chance to win his case defending Tom because Tom was black offered the most explicit indicator of deep-rooted racism. Lee's closing argument in Chapter 20 clearly outlined Atticus's views on racism. However, Lee also showed us prejudice as it pertained to gender and social class.

Another symbolic significance of the mockingbird is the the coexistence of good and evil. The most important theme of To Kill a Mockingbird is the book's exploration of the moral nature of human beings, that is, whether people are essentially good or essentially evil. The novel approaches this question by dramatizing Scout and Jem's transition from a perspective of childhood innocence, in which they assumed that people were 
good, because they had never seen evil, to a more adult perspective, in which they had confronted evil and must incorporate it into their understanding of the world.

The moral voice of To Kill a Mockingbird is embodied by Atticus Finch, who is virtually unique in the novel in that he experienced and understood evil without losing his faith in the human capacity for goodness.

The novel exposes the loss of innocence (and innocents) so frequently that reviewer R. A. Dave claims it is inevitable that all the characters have faced or will face defeat, giving it elements of a classical tragedy (Frank, 2004, p. 95). "In exploring how each character deals with his or her own personal defeat, Lee builds a framework to judge whether the characters are heroes or fools" (Zhang, 2006, p. 109). She guides the reader in such judgments, alternating between unabashed adoration and biting irony.

Besides the characters and Gothic motifs, the mockingbird also carries symbolic significance in the novel, which not only reveals the author's real attitudes towards the society, but also adds to the attraction of the book.

\section{Conclusion}

In To Kill a Mockingbird, the author skillfully uses the symbols to make the novel more artistically charming. Different kinds of symbols contribute in the themes, making the book have more space to think and represent abstract ideas or concepts. The use of symbols in To Kill a Mockingbird enhances the readability of the novel, giving their works a special artistic charm and making it pass down among the enduring masterpieces. The author deepens the themes, which is exploration of the moral nature of human beings, that is, whether people are essentially good or essentially evil. The author reveals the evil society and the evil side of the human nature from the aspects of the characters, Gothic motifs, and the mockingbird. The paper explains what the symbols really represent so as to help readers understand the article in a new way.

\section{References}

Claudia, D. J. (1994). To kill a mockingbird -Threatening boundaries. New York, N.Y.: Twayne Publishers.

Conway, M. R. (2007, March 17). The elusive symbolist movement. International Herald Tribune, p.16.

Ellis, M. (2000). The history of Gothic fiction. Edinburgh: Edinburgh University Press.

Frank, F. S. (2004). Guide to the Gothic III: An annotated bibliography of criticism, 1993-2003. Lanham: Scarecrow Press.

Harper, L. (1988). To kill a mockingbird. New York, N.Y.: Grand Central Publishing.

Hassan, I. (1961). Radical innocence: Studies in the contemporary American novel. Princeton, N.J.: Princeton University Press.

Marie, M. R. (1998). The handbook to Gothic literature. New York, N.Y.: New York University Press.

Meyer, H. A. (2004). A glossary of literary terms. Beijing: Foreign Language Teaching and Research Press.

Shaffer, D. R. (2005). Developmental psychology. Beijing: China Light Industry Press.

Zhang, Z. Z. (2006). Selected readings in classical Western critical theory. Beijing: Foreign Language Teaching and Research Press. 